\title{
Mapping the Potential Liquefaction Area in Yogyakarta City Based on Ground Shear Strain Data
}

\author{
Ilham*, ${ }^{1}$ Urip Nurwijayanto Prabowo, ${ }^{2}$ and Sismanto ${ }^{3}$ \\ ${ }^{1}$ Physics Education Department, Universitas Islam Negeri Mataram, Jl. Gadjah Mada 100, Mataram 83116, Indonesia \\ ${ }^{2}$ Physics Department, Universitas Jenderal Soedirman, Jl. Prof. HR Bunyamin 708, Purwokerto 53122, Indonesia \\ ${ }^{3}$ Geophysics Department, Universitas Gadjah Mada, Sekip Utara, Bulak Sumur, Sleman 55281, Indonesia
}

\begin{abstract}
The appearance of liquefaction phenomena in some places in Yogyakarta city due to the 2006 earthquake indicates that the sediment in this area has a high potential to liquefy. Three main factors that caused liquefaction are ground shaking, lithological conditions, and groundwater depth. This study aims to investigate one of the three factors i.e ground shaking. For this purpose, the ground shear strain (GSS) data were analyzed for mapping the potential liquefaction area in Yogyakarta city. They were calculated from the seismic vulnerability index and PGA. The seismic vulnerability index was analyzed from a microtremor single station data recorded in 110 sites while PGA was calculated using a reference of the 2006 earthquake. The GSS value in the study area is at a range of $2.0 \times 10^{-4}$ to $5.8 \times 10^{-3}$. In this range, the soils begin to be elasticplastic so that they are susceptible to be fracture and settlement. The high GSS correlates with the location of the liquefaction due to the 2006 earthquake. The liquefaction potential map was obtained by comparing the GSS with liquefaction sites. The high liquefaction potential is located in the southern part of Yogyakarta city covering Mantrijeron, Mergangsan, Pakualaman, Umbulharjo, and Kotagede districts.
\end{abstract}

Keywords: liquefaction; microtremors; ground shear strain

*Corresponding author: ilham.fisika@uinmataram.ac.id

Article history: Received 30 Juni 2021, Accepted 23 September 2021, Published October 2021. http://dx.doi.org/10.12962/j24604682.v17i3.9561

2460-4682 (C)Departemen Fisika, FSAD-ITS

\section{INTRODUCTION}

Yogyakarta is a vulnerable area of the earthquake. Historically, large earthquakes often shake this area in the past. They occurred in 1867, 1937, 1943, 1976, 1981, 2001, and 2006 [1]. The most destructive earthquake occurred on 27 May 2006. The earthquake with a moment magnitude (Mw) of 6.3 caused 195 people's death, 318 people injured, 7188 buildings collapsed, 14691 heavily damaged, and 21,230 lightly damaged [2].

The 2006 Yogyakarta earthquake caused a secondary effect in the form of the liquefaction phenomenon. Liquefaction involves a phenomenon of the decay of shear resistance and extreme deformation caused by monotonic or repeated loading of saturated soils [3]. As a consequence of liquefaction, soils behave as a viscous liquid [4]. The liquefaction phenomenon in Yogyakarta can be observed with the appearance of sand boils, fractures, and lateral spreadings that was spread at some sites in the Yogyakarta area. It was spread on the west side of the Opak Fault trending NE-SW and turn towards the east in around Klaten [5] (Fig. 1).

Three main factors that can generate liquefaction are ground shaking, lithological conditions, and saturated sediment by groundwater [6]. Liquefaction occurred if there was a ground-shaking especially an earthquake shaking. The magnitude and epicenter distance of earthquakes influenced liquefaction susceptibility. Liquefaction occurred in non-cohesive soils. The types of soil that can liquefy are water-saturated sand, fine to slightly coarse in diameter, or sandy-silt soil, especially if the drainage system is not good. Liquefaction occurs only in saturated soils, so the depth to groundwater influences liquefaction susceptibility. Liquefaction susceptibility decreases with increasing groundwater depth. The effects of liquefaction are most commonly observed at sites where groundwater is within a few meters of the ground surface.

In the eastern part of Yogyakarta city, there is an earthquake source associated with the Opak fault that can be a source of ground shaking. This area is also dominated by the thick volcanic sediment from Merapi Volcano composed of tuff, ash, breccia, agglomerate, and lava flows [7] that can strengthen earthquake shaking. The groundwater depth in this area is also very shallow which range between $2.1-12.7 \mathrm{~m}$ [8]. Based on this condition, the soil in Yogyakarta city has a high potential to liquefy.

The study about liquefaction in Yogyakarta Province especially in Bantul Regency, the southern part of Yogyakarta Province, has been carried out using CPT and N-SPT [9], shaking table [10], cyclic triaxial testing [11], and shear velocity profiling [12]. In this study, we investigated the vulnerability of liquefaction in Yogyakarta city, the capital of Yogyakarta Province, using ground shear strain (GSS) data. The data describe the area that will be stretching or shifting during the earthquake [13]. They describe the liquefaction potential level caused by a ground shaking especially an earthquake shaking. The GSS value can be calculated from the seismic vulnerability index $\left(K_{g}\right)$ and peak ground acceleration (PGA). 


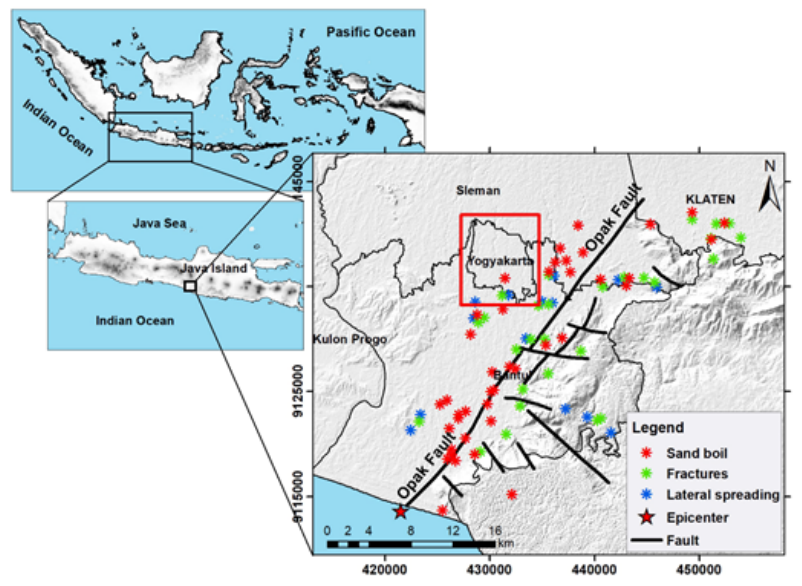

FIG. 1: Liquefaction sites due to the 2006 Yogyakarta earthquake (modified from [5]).

According to [14] and [15], in GSS value is more than $10^{-2}$ liquefaction occur.

The mapping of liquefaction potential in Yogyakarta city is very important. This city is the center of the government of Yogyakarta Province. Many buildings and infrastructures such as schools, colleges, hospitals, hotels, and industries are located here. Historically, some liquefaction phenomena, a secondary effect of the earthquake, caused more damage than the earthquake. Thus, this study will be one of the disaster mitigations to reduce the potential damage if the liquefaction phenomenon will occur in the future.

\section{METHOD}

The study area is located in Yogyakarta city geographically at $110^{\circ} 24^{\prime} 19^{\prime \prime}-110^{\circ} 28^{\prime} 53^{\prime \prime}$ E and 7 $15^{\prime} 24^{\prime \prime}-7^{\circ} 49^{\prime} 26^{\prime \prime}$. The seismic vulnerability index $\left(K_{g}\right)$ in the study area was analyzed from the microtremor single stations data recorded in 110 sites shown in Fig. 2. The data were recorded using a TDV 23S feedback short-period seismometer. The recording duration was 30 - 60 minutes with the sampling rate was 100 $\mathrm{Hz}$. The data were recorded at night to minimize the noise caused by human activities.

Microtremor data were processed using Geopsy to get a Horizontal to Vertical Spectral Ratio (HVSR) curve. It was done by selecting some stationer signals with time windows $50 \mathrm{~s}$ in length. The smoothing type from Konno Ohmachi was chosen with a smoothing constant of 20 . From each HVSR curve, a peak amplification factor and a fundamental frequency value were obtained. A peak amplification factor was obtained from the highest amplitude on the HVSR curve while the fundamental frequency was a frequency at the peak amplification factor. These values were used to calculate the seismic vulnerability index using Eq. 1 given by [13] as

$$
K_{g}=\frac{A_{0}^{2}}{f_{0}}
$$

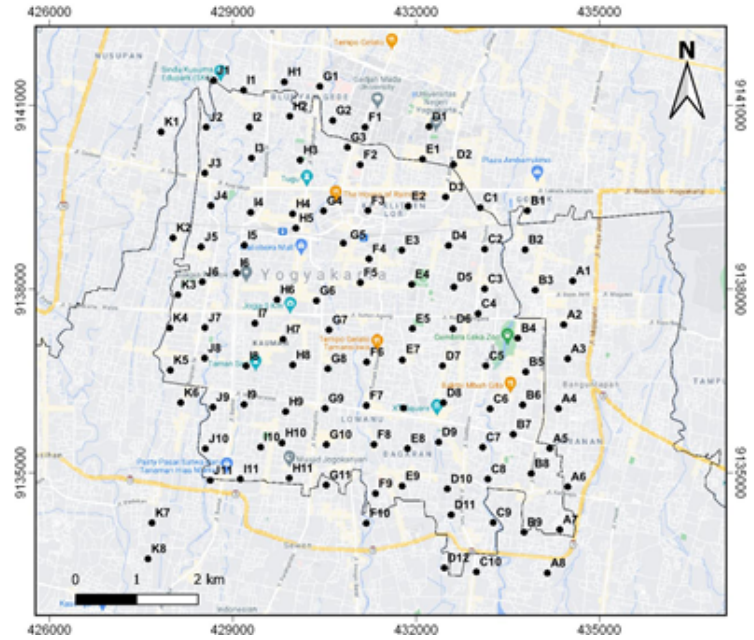

FIG. 2: Measurement points of microtremor single station (black dots).

where $K_{g}$ is a seismic vulnerability index, $A_{0}$ is a peak amplification factor, and $f_{0}$ is a fundamental frequency.

The peak ground acceleration (PGA) in the basement was calculated by empirical equation from [16] as presented in Eq. 2.

$$
\begin{array}{r}
\log \alpha=0.42 M_{w}-\log \left(R+0.025 \times 10^{0.42 M_{w}}\right) \\
-0.0033 R+1.22-0.14 L
\end{array}
$$

where $\alpha$ is PGA in $\mathrm{cm} / \mathrm{s}^{2}, M_{w}$ is the moment magnitude, $R$ is the closest distance from the fault plane to the site $(\mathrm{km})$, and $L$ is the dummy variable, which equals 0 for Japan, 1 otherwise. In this study, the reference is the earthquake that occurred on May 27, 2006, with a magnitude of 6.3 and a hypocenter depth of $12.5 \mathrm{~km}$.

Finally, the ground shear strain values were calculated using Eq. 3 given by [13] as

$$
\gamma=K_{g} \times 10^{-6} \times \alpha
$$

Seismic vulnerability index, PGA, and GSS were calculated using Ms. Excel. The GSS values were interpolated by Surfer with gridding methods of Kriging. While the map was made using QGIS.

\section{RESULTS AND DISCUSSION}

\section{A. HVSR Curve}

The processing of microtremor single station data in Yogyakarta city produces several types of HVSR curves. The HVSR curves are grouped into several types based on the types of HVSR peaks created by [17]. They are grouped based on the shape of the peak of the curve. The types of HVSR curves in Yogyakarta are (1) single peaks; (2) two peaks; (3) multiple peaks; and (4) flat peaks that can be seen in Fig. 3. 


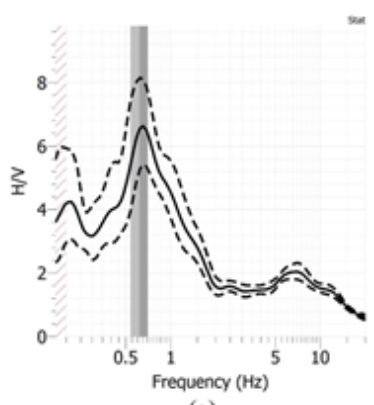

(a)

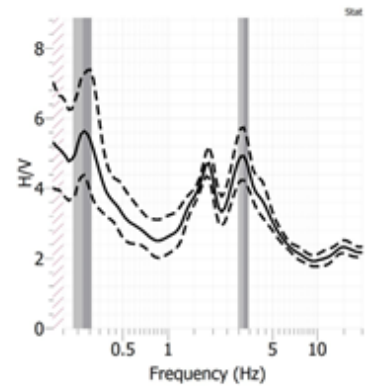

(c)

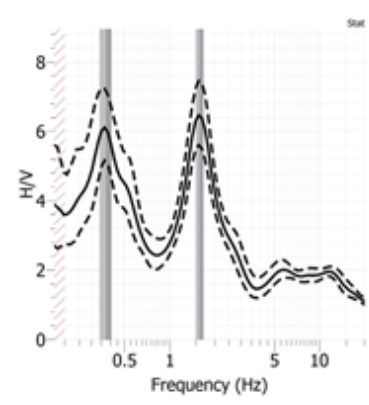

(b)

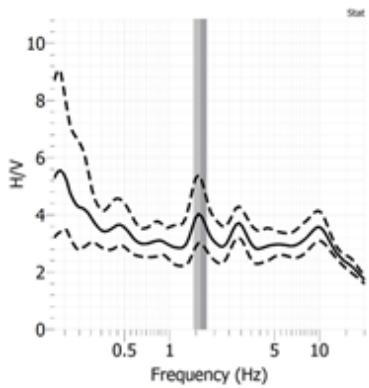

(d)
FIG. 3: The types of HVSR curve in Yogyakarta city: (a) single peak at point $\mathrm{G} 1$, (b) two peaks at point D11, (c) multiple peaks at point $\mathrm{H} 8$, (d) flat peak at point $\mathrm{K} 2$.

The two peaks and multiple peaks are spread in the middle to the east and south. According to [18] these peaks can be interpreted as the natural frequencies of one sedimentary layer. But, according to [17], the two peaks can be interpreted as two fundamental frequencies of two sedimentary layers that have a large impedance contrast. To determine which one of both interpretations is correct, we analyze the characteristic of frequency response and compare it with the depth of sedimentary layers in the study area.

According to [18], the peak amplification factor decreases with increasing the natural frequency that is caused by the damping effect. But, most of the HVSR curves in this study show that the high natural frequency has a higher peak amplification factor than the lower frequency, as shown by the HVSR curve in Fig. 3b. Besides that, both natural frequencies must describe the same depth of sedimentary layer [18]. But, when we calculate the depth of the sedimentary layer using both natural frequencies where the shear velocity is given by [19], we obtain different depths. Thus, it is less true if we interpret the two peaks as the natural frequencies of one sedimentary layer.

The interpretation of the two peaks as the two fundamental frequencies is closer to the truth because it has a high correlation with the geological conditions of Yogyakarta city. The two peaks, namely $f_{0}$ and $f_{1}$, describe the two sedimentary layers. The Yogyakarta city is a basin composed of two sedimentary formations namely Sleman formation and Yogyakarta formation [7]. The Sleman Formation at the bottom consists of volcanic sandstone and gravel interspersed with andesite boulders. While the Yogyakarta Formation at the top

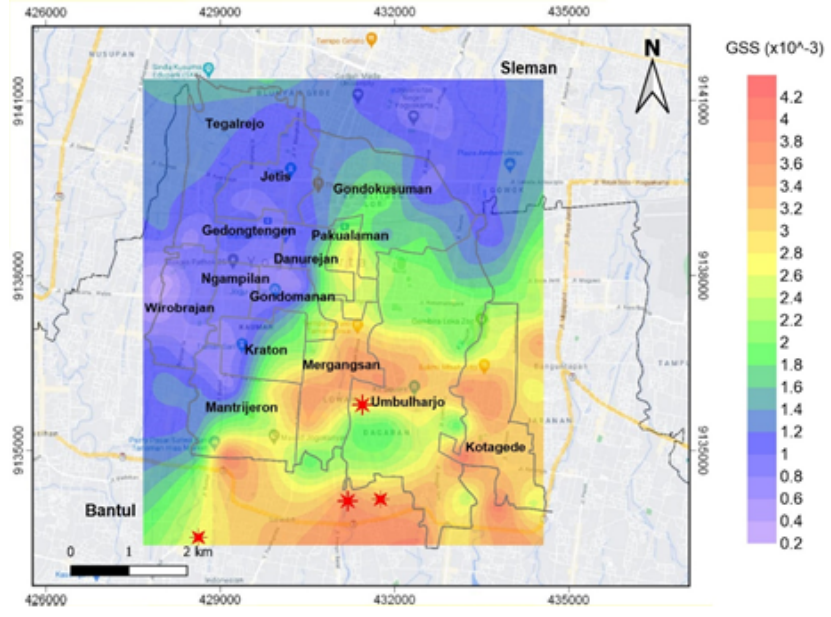

FIG. 4: Ground shear strain map in study area overlayed with liquefaction sites (red stars) due to 2006 Yogyakarta earthquake.

is composed of sand, gravel, silt, and volcanic clay. In addition, in this middle part, the thickness of the Sleman formation and Yogyakarta formation is quite significant. At this location, the thickness of the Sleman Formation is $105 \mathrm{~m}$, while Yogyakarta Formation is $45 \mathrm{~m}$. The contrast impedance and sediment thickness of the two formations is what causes the appearance of two peaks on the HVSR curve. For multiple peaks, we choose the two peaks that have a good correlation with the depth of the sedimentary layer in the study area.

The single peak spread over many points in the northern part of Yogyakarta city. It shows that at that location there is only one layer of sediment. This result does not contradict the results obtained previously. In this case, the impedance contrast between the two sediment layers is absent, and the effects of one layer are absorbed by the other [20]. In addition, this is also caused by the thickness of the Yogyakarta formation and Sleman formation which is not too significant. The thickness of the Sleman and Yogyakarta formations in the north is $20 \mathrm{~m}$ and $25 \mathrm{~m}$ respectively [7].

The flat peak is spread in the western part of the city. On this type, the peak is not visible clearly. This indicates that the soil in this location is hard [17]. This result correlates with the appearance of Sentolo formation in the west of Yogyakarta city. This formation consists of limestone, marl, and tuff [7] which is well exposed in the southwest of the study area.

In the case of two peaks curve, the high-frequency peak corresponds to the shallow layer, while the low-frequency peak corresponds to the deep layer [17]. According to history, liquefaction occurs in shallow layers. Thus, the liquefaction potential analysis was only carried out at high-frequency peaks.

\section{B. Liquefaction Potential Map}

The ground shear strain (GSS) value in the study area was calculated using Eq. 3. The results of the interpolation of these values can be seen in Fig. 4. The map is also over- 


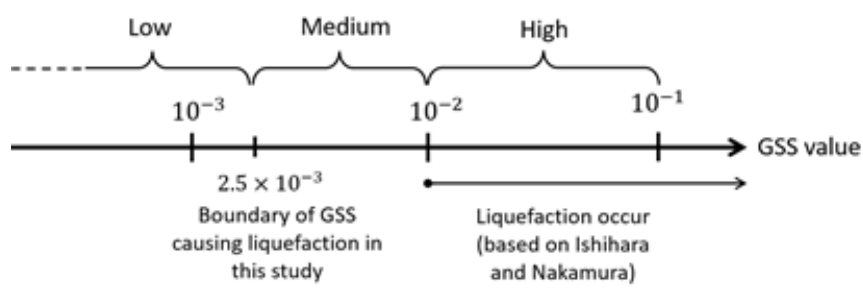

FIG. 5: Analysis of classification of liquefaction potential level in Yogyakarta city.

TABLE I: Classification of liquefaction potential in Yogyakarta city

\begin{tabular}{cc}
\hline Ground shear strain & Liquefaction potential \\
\hline$\gamma>1.0 \times 10^{-2}$ & High \\
$2.5 \times 10^{-3}<\gamma<1.0 \times 10^{-2}$ & Medium \\
$\gamma<2.5 \times 10^{-3}$ & Low \\
\hline
\end{tabular}

laid with the location of liquefaction caused by the 2006 Yogyakarta earthquake.

The GSS value in the study area is at a range of $2.0 \times$ $10^{-34}$ to $4.2 \times 10^{-3}$. In this range, the soils begin to be elastic-plastic so that they are susceptible to be fracture and settlement [14]. The high GSS is located in the center to the south of Yogyakarta City covering Mantrijeron, Mergangsan, Pakualaman, Umbulharjo, and Kotagede districts. In the northern and western parts of the study area, the GSS is low. There is a high correlation between the GSS map and liquefaction sites to the 2006 earthquake. The liquefaction phenomena correspond to the high GSS found in the southern part of the study area. Thus, the sedimentary layer in the southern part of Yogyakarta city has a high potential to liquefy.

For mapping the liquefaction potential level, we analyze the GSS value at the liquefaction sites due to the 2006 earthquake in Fig. 4. The GSS values at the sites are $2.9 \times 10^{-3}, 3.4$ $\times 10^{-3}, 2.5 \times 10^{-3}$, and $3.2 \times 10^{-3}$. The minimum value of them is $2.5 \times 10^{-3}$. This value is lower than the minimum value of GSS causing liquefaction as proposed by [14] and [15]. This result provides new information in the analysis of liquefaction. This minimum value is used as a boundary condition for mapping liquefaction potential in the study area. It makes sense if the minimum GSS value at the liquefaction sites is used as a boundary condition for mapping liquefaction potential. We use the 2006 earthquake as a reference for calculating the GSS and we compare it with the liquefaction site due to the 2006 earthquake.

Liquefaction potential level in Yogyakarta city was classified by combining the theory of [14] and [15] and the boundary condition above. Analysis of the classification can be seen in Fig. 5. According to [14] and [15], liquefaction occurs if GSS is more than $1.0 \times 10^{-2}$. Thus, the area with GSS is more than $1.0 \times 10^{-2}$ is classified as a high level. The boundary of GSS that can generate liquefaction obtained in this study is $2.5 \times 10^{-3}$. Thus, the area with the GSS between $2.5 \times 10^{-3}$ and $1.0 \times 10^{-3}$ is classified as a medium level. The area with GSS is less than $2.5 \times 10^{-3}$ is classified as a low level. The summary of this classification can be seen

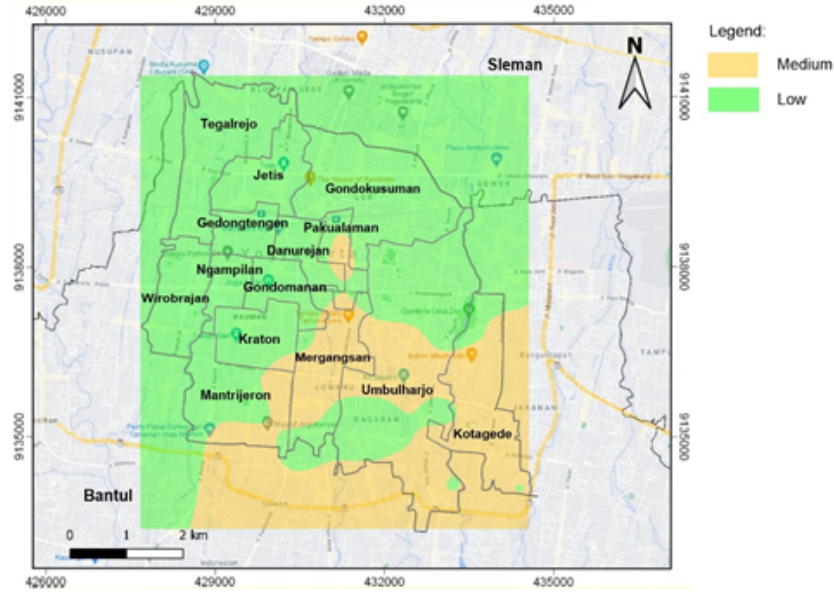

FIG. 6: The liquefaction potential map in Yogyakarta city.

in Table 1.

The mapping of liquefaction potential in Yogyakarta city used the classification above can be seen in Fig. 6. The liquefaction potential in Yogyakarta city is in medium and low levels. The medium level is located in the southern part of Yogyakarta city covering Mantrijeron, Mergangsan, Pakualaman, Umbulharjo, and Kotagede districts. While the low level is at the northern part of Yogyakarta city. This map can be used as a reference in the development of urban land used plans especially in the southern part of Yogyakarta city.

The liquefaction potential map in Yogyakarta city may change if the magnitude and the epicenter of the earthquake are different from the earthquake reference used in this study. In this study, the reference is the 2006 Yogyakarta earthquake with a moment magnitude (Mw) of 6.3 , and the distance of the epicenter is $20 \mathrm{~km}$ from Yogyakarta city. If the earthquake in the future has a larger magnitude and a closer hypocenter, the liquefaction potential will be higher.

\section{SUMMARY}

The liquefaction potential in Yogyakarta city was mapped based on ground shear strain (GSS). The GSS value is at a range of $2.0 \times 10^{-4}$ to $4.2 \times 10^{-3}$. According to the GSS value at the liquefaction site due to the 2006 earthquake, the minimum value of GSS that can generate liquefaction is 2.5 $\times 10^{-3}$. This minimum value is used as a boundary condition in mapping the liquefaction potential area in this study. Liquefaction potential level was classified by combining the theory and the boundary of GSS obtained in this study. The liquefaction potential in Yogyakarta city is in medium and low levels. The medium level is located in the southern part while the low level is at the northern part of Yogyakarta city. For future research, it is very important to conduct research using other methods focused on the southern part of Yogyakarta city to obtain more detailed information. It should be done as one of the disaster mitigations to reduce the potential damage if the liquefaction phenomenon will occur in the future. 


\section{Acknowledgment}

Thanks to the Meteorology, Climatology, and Geophysical
Agency (BMKG) of Yogyakarta for assisting in the process of acquiring data of microtremor single station.
[1] BAPPENAS-BAPEDA DIY-UNDP, Profil Kebencanaan Provinsi Daerah Istimewa Yogyakarta 2008. Yogyakarta: BAPEDA DIY, 2008.

[2] BAPPENAS, "Preliminary Damage and Loss Assessment Yogyakarta and Central Java Natural Disaster," Jakarta, 2006.

[3] R. Cudmani, "Soil Liquefaction: Mechanism and Assessment of Liquefaction Susceptibility," in International Conference on Seismic Design of Industrial Facilities, 2013.

[4] K. Kumar, Basic Geotechnical Earthquake Engineering. New Delhi: New Age International, 2008.

[5] E. Soebowo, A. Tohari, and D. Sarah, "Studi Potensi Likuifaksi di Daerah Zona Patahan Opak Patalan-Bantul, Jogjakarta," in Proseding Seminar Geoteknologi Kontribusi Ilmu Kebumian Dalam Pembangunan Berkelanjutan, 2007, pp. 5565.

[6] M. Jefferies and K. Been, Soil Liquefaction, A Critical State Approach. USA: Taylor Francis, 2006.

[7] D. P. E. Putra, M. Iqbal, H. Hendrayana, and T. T. Putranto, "Assessment of Optimum Yield of Groundwater Withdrawal in The Yogyakarta City, Indonesia," J. SE Asian Appl. Geol, vol. 5, no. 1, pp. 4149, 2013.

[8] Y. P. Kurniawan, "Pengaruh Kondisi Hidrogeologi dan Sanitasi Lingkungan Terhadap Tingkat Kandungan Bakteri Coli Pada Air Tanah Dangkal Tahun 2012 di Kota Yogyakarta," Universitas Gadjah Mada, 2014.

[9] E. Soebowo, A. Tohari, and D. Sarah, "Potensi Likuifaksi Akibat Gempabumi Berdasarkan Data CPT dan N-SPT di Daerah Patalan Bantul, Yogyakarta," J. Ris. Geol. dan Pertamb., vol. 19, no. 2, pp. 8597, 2009, doi: 10.14203/risetgeotam2009.v19.25.

[10] L. Z. Mase, 'Experimental Liquefaction Study of Southern Yogyakarta Using Shaking Table," J. Tek. Sipil, vol. 24, no. 1, pp. $1118,2017$.

[11] R. Kusumawardani, K. B. Suryolelono, B. Suhendro, and A. Rifai, "Dynamic Behaviour of Yogyakartas sand Under Cyclic
Triaxial Testing," Int. J. Civ. Environ. Eng., vol. 12, no. 02, pp. 2328, 2013.

[12] E. Hartantyo, K. S. Brotopuspito, Sismanto, and Waluyo, "Predicting the Liquefaction Phenomena from Shear Velocity Profiling: Empirical Approach to 6.3 Mw, May 2006 Yogyakarta Earthquake," in AIP Conference Proceedings, 2015, pp. 110.

[13] Y. Nakamura, "On the H/V Spectrum," in The 14th World Conference on Earthquake Engineering, 2008, pp. 110.

[14] K. Ishihara, Soil Behaviour in Earthquake Geotechnics. Great Britain: Clarendon Press, 1996.

[15] Y. Nakamura, "Seismic Vulnerability Indices For Ground and Structures Using Microtremor," in World Congress on Railway Research, 1997, vol. 1, pp. 17.

[16] Y. Fukushima, O. Köse, T. Yürür, P. Volant, E. Cushing, and R. Guillande, "Attenuation Characteristics of Peak Ground Acceleration from Fault Trace of The 1999 Kocaeli ( Turkey ) Earthquake and Comparison of Spectral Acceleration with Seismic Design Code," J. Seismol., vol. 6, pp. 379396, 2002.

[17] SESAME, "Guidelines for the Implementation of the H/V Spectral Ratio Technique on Ambient Vibrations Measurements, Processing, and Interpretation," 2004.

[18] S. L. Kramer, Geotechnical Earthquake Engineering. United State of America: Prentice-Hall, 1996.

[19] M. Muzli et al., "Pengukuran Vs30 Menggunakan Metode MASW Untuk Wilayah Yogyakarta," J. Meteorol. dan Geofis., vol. 17, no. 1, pp. 2532, 2016, doi: 10.31172/jmg.v17i1.374.

[20] Z. L. Kyaw, S. Pramumijoyo, S. Husein, T. F. Fathani, and J. Kiyono, "Seismic Behaviors Estimation of the Shallow and Deep Soil Layers Using icrotremor Recording and EGF Technique in Yogyakarta City, Central Java Island,' Procedia Earth Planet. Sci., vol. 12, pp. 3146, 2015, doi: 10.1016/j.proeps.2015.03.024 